Sign Systems Studies 28, 2000

\title{
Mereology and semiotics
}

\author{
Frederik Stjernfelt \\ Dept. of Comparative Literature, University of Copenhagen, \\ Njalsgade 80A, 2300 Copenhagen, Denmark \\ e-mail: stjern@hum.ku.dk
}

\begin{abstract}
This paper gives a first overview over the role of mereology the theory of parts and wholes - in semiotics. The mereology of four major semioticians - Husserl, Jakobson, Hjelmslev, and Peirce is presented briefly and its role in the overall architecture of each of their theories is outlined - with Brentano tradition as reference. Finally, an evaluation of the strength and weaknesses of the four is undertaken, and some guidelines for further research is proposed.
\end{abstract}

Strange as it may seem, mereology — the theory of parts and wholes $^{1}$ - has only rarely caught the explicit attention of semiotics.

\footnotetext{
1 "Mereology", from Greek meros, part. As a matter of fact, it might have been called "merology", but after the Polish logician Lesniewski the form quoted has become ubiquitous. Lesniewski, in his works from the 20 s and $30 \mathrm{~s}$, considered mereology to be one out of three basic branches of philosophy, "protothetic", "ontology", and "mereology", respectively. Protothetic is a doctrine of propositions and their interrelations and it forms the logical basis of his theory; ontology is based on a distributive rendering of class membership, so that distributive class expressions are identical with general nouns applicable to individuals. Mereology, then, considers collective class expressions understood as being composed of parts. By the distinguishing of the two latter branches of philosophy, Russell's paradox is avoided: there is no such thing as a class containing itself. Mereology is weaker than set theory in so far as it only admits one relation of inclusion (part of), opposed to the two in set theory (membership relation and subset relation, which in Lesniewski's thought is separated as belonging to ontology and mereology, respectively). Mereology in this sense of the word thus has the advantage of being "bottomless", the compositional foundation of a class upon the existence of ultimate members being avoided. This implies that mereology is "phenomenological" in so far as it may describe a given level of phenomenal existence without recourse to a bottom level of atomistic ontology, a crucial aspect of the semi-
} 
Semiotics as a study taking significant phenomena in general as its object, is faced with the problem of the signification of wholes in relation to the signification of its parts as a completely everyday phenomenon, and the recognition of distinct levels or layers of signification is also a well-known idea in most parts of semiotics. Taking the prototypical case of a text as an example, semiotics is faced not only with the traditional linguistic question of the organization of phonemes and morphemes into words, and in turn, words into sentences by means of syntax, but also, in turn, the successive integration of sentences into more extensive wholes of transphrastic discourse, periods, scenes, scripts, narrations, genres, systems of ideas, etc. As is the case in the sciences more generally, this mereological problem gives rise to two typical approaches; the one, reductionist, takes a compositional attitude to the signification of wholes which is consequently seen as some kind of sum of its elements, so that an algorithmic syntax of some sort is supposed to make it possible to derive the whole's signification from the knowledge of the signification of its parts. The second, holist, stance takes the signification of the higher levels as irreducible, relying on their own phenomenological motivation, and, correlatively, the parts as being an analytical result of a partitioning of the whole, expanding the possibilities of the whole and making its signification in the single case more precise. ${ }^{2}$

otic perspectives in mereology. This implies the possible affinity of mereology to strongly nominalist positions claiming mereology to be without any ontological presuppositions whatsoever (as in Lesniewski's case, and after him, Goodman) - even if this is no necessity, and mereology may as well be connected to realist positions, for an actual example: Barry Smith. Lesniewski was influenced by the part-whole reflections of the Brentanian tradition: Husserl's 3rd and 4th Logical Investigations, in turn influenced by Brentano's Deskriptive Psychologie (1890), and Carl Stumpf's Über den psychologischen Ursprung der Raumvorstellung (1873). For further accounts for these developments, see Smith $(1982,1994)$. In this essay, we shall stick to mereological aspects of decidedly semiotic currents of thought.

Even if none of the four authors discussed here use the word, I have chosen it as a shorthand for "doctrine of whole and parts" and similar more complicated expressions.

2 Of course, each of these two alternatives displays a host of subvariants of more and less sophisticated types, ranging from a completely compositional logicist theory in the one end and to almost mystical insistances on the wholes' autonomy in the other. Moreover, there is not necessarily a contradiction between the two; it is perfectly possible to imagine compromises, so as, e.g., an emphasis on the primacy of the holist level giving rise to motivated, iconic syntaxes governing its parts — combined with a recognition of the possibility for these syntaxes of assuming, once established, an autonomous status involving local compositionality. 
In this paper I shall briefly discuss the mereological implications in four major trends of semiotics with different degrees of connection to the Brentanian tradition in philosophy from which modern mereology originate, namely Husserl, Jakobson, Hjelmslev, and Peirce. Husserl, of course, is a Brentanian, and in his famous 3rd Logical Investigation, he outlines a theory of parts and wholes as a part of formal ontology. The second, Jakobson, has direct connections to this tradition, primarily via Husserl; the third, Hjelmslev, displays striking similarities with the tradition without any direct influence admitted; the fourth, Peirce, working simultaneously with Brentano, has no relation at all to the tradition but still structural similarities abound.

\section{Husserl}

It is strange how little Husserl's work is recognized or even known in the semiotic world. In fact, most of his work either explicitly deals with or at least touches upon issues central to semiotics. In his early work, around the period of the Philosophie der Aritmetik, he even uses the word himself ${ }^{3}$, and later, in his chef-d'oeuvre Logische Untersuchungen (1900-1901), he investigates a whole series of central semiotic questions. Logische Untersuchungen ought to count as a classic of semiotics. Its long Prolegomena contains a detailed attack on psychologism in logic and semiotics - in so far it constitutes a major contribution to the fundamental anti-psychologism of general semiotics alongside Peirce's strongly related position. The first investigation draws a distinction between two sign types, Ausdrücke and Anzeichen, respectively: signs conferring meaning to an object vs. signs merely indicating an object. The second investigation is a critique of empiristic abstraction theories attempting to make induction the source of abstract knowledge — and it points instead to a phenomenological change in conception modus as responsible for abstraction's grasp of ideal objects. The third investigation, to which we shall return below, constructs the foundations for a formal ontology of wholes and parts which form a basis for all phenomenological and semiotic investigations in so far as it makes possible to distinguish proper parts from non-proper parts, the last including what is usually called properties. The fourth investigation takes the mereology of the third as the foun-

3 Cf. Husserliana XII which contains among other writings "Zur Logik der Zeichen (Semiotik)". 
dation of a pure, that is, a priori grammar, mapping dependence relations between linguistic entities; nouns and sentences are taken as independent primitives which other linguistic entities are dependent upon. The fifth investigation is the first sketch of Husserl's intention theory, distinguishing between the quality, the matter, the representative content, and the object of an act, respectively. The quality is in our days' terms a speech act category; it refers to the act's character of being propositional, imperative, wishing, etc. The matter of the act is the way its object is presented in the act, and the representative content, finally, is the degree of fulfilment with which the object is presented (perception representing the highest degree of fulfilment, and linguistic representations ("signitive acts") and imaginations ("imaginative acts") like fantasies, pictures, dreams, memories, etc. being act types with lower degree of fulfilment). All these aspects of the act are presented as moments, that is, "unechte Teile", in the terminology of the third investigation ${ }^{4}$. Finally, the sixth investigation takes up epistemology on the basis outlined in the former investigations; here, the central problem of categorial intuition (how categories, among them linguistic categories, possess their own type of intuitive fulfilment ${ }^{5}$ ) is discussed.

As is evident, most of the issues discussed in the Logische Untersuchungen lie at the heart of semiotics, and the mereology of the third investigation forms a crucial piece of formal ontology for the description of all these subjects. The main idea is that all objects may be described in terms of parts and wholes, and that two types of parts may be distinguished. Proper parts and non-proper parts, or, parts versus moments, respectively. Parts — "echte Teile", or "Stücke", or concrete parts - are parts which may be separated from the whole they constitute, while moments - "unechte Teile", or aspects, or abstract parts - are parts which may not be so separated. This sparse definition may be extended to relative autonomy and dependence, respectively, so that one object is relatively dependent on another if that content may only exist in connection to the other or parts of it. This idea makes possible the crucial structure of three possible dependence relations between parts:

As a matter of fact, the question of whether the object is a genuine part or a moment of the act is crucial to the division between realist from transcendental ontology.

5 I discuss the categorial intuition concept and its extension in Stjernfelt (forthcoming a). 
"Fassen wir irgendein Paar von Teilen eines Ganzen ins Auge, so bestehen folgenden Möglichkeiten:

1. Zwischen beiden Teilen besteht ein Verhältnis der Fundierung.

2. es besteht diese Verhältnis nicht. Im ersteren Falle kann die Fundierung

a) eine gegenseitige,

b) eine einseitige sein ...” (Husserl 1984: 264-265).

Husserl's mereological investigations includes further points of interest - so as for instance the difference between wholes requiring a moment of unity and wholes not requiring it. Smith (1994: 236) summarizes Husserl's ideas in a small taxonomy. Between wholes, Husserl distinguishes those which do not require additional objects to exist (such as nut and bolt), opposed to those that require additional unifying objects (such as nails or glue). The last category yields two subtypes, depending on whether the unifying object is a concrete part or an abstract moment. In the latter case, he moment of unity will correspond to von Ehrenfels's Gestaltqualitäten.

This distinction is related to different versions of gestalt theory, cf. Barry Smith's recapitulation of the Austrian gestalt school's "production theory" requiring such a moment of unity in addition to the parts, as opposed to the Berlin gestalt school's claim that no parts of a gestalt are genuine and all parts are moments only accessible by abstraction. (Smith 1994: ch. 8). Both schools' theories have their advantages and flip sides. The Graz school has the advantage of distinguishing between a part and the role played by that part in the gestalt in question, while the Berlin school tends to blur this distinction and construct a holism. The Graz school, on the other hand, tends to come close to Helmholtz's old idea of gestalt-like phenomena being the result of "unbewusste Schlüsse" so as to make them an additional feature added to sense data by the intellect - while on the other hand the Berlin school does not follow this subjectivist idea: its holism has the merit of integrating both subjective and objective determinants as responsible for the gestalt, and so the Berlin school will find gestalts not only in the physiology of the gestalting subject, but also in the purely objective, even physical surroundings. Smith's conclusion is not unanimous, but it seems as if the two schools correspond to different gestalt possibilities on a continuous scale rather than being mutually exclusive, so that both very subjective and very objective gestalts as well as a large range of intermediate types are possible. We can not go further into this huge discussion here, but a further clarification of types and subtypes of gestalts and their 
types and subtypes of gestalts and their relation to their parts will no doubt enrich the semiotic discussion of mereology.

Finally, Husserl's fourth Investigation should be added. Here, he outlines a pure, a priori grammar using the mereological tools of the third Investigation - an idea, as a matter of fact, closely related to Hjelmslev's idea (cf. below). In contradistinction to Hjelmslev's empirical idea of using mereology as a descriptive metalanguage for linguistics, Husserl's idea is to base the mereological description of language on certain ontological presuppositions, namely the privileging of the noun and sentence, respectively, as independent entities (after the Scholastic distinction between kategorematica and synkategorematica, respectively, the former possess an autonomous signification). Furthermore, Husserl defines the important distinction between Widersinn and Unsinn, respectively - logical and grammatical nonsense, respectively, where the latter depends on irreconcilable syncategorematica being combined, while the former is grammatical correct while contradictory. Husserl's sketches of a pure grammar received more interest in logic than in linguistics: they became very important for Ajdukiewicz, Lesniewski, and the development of categorial grammar. But even so, a volume like the brillant Rational Grammar by Jean-Louis Gardies not only outlines the Wirkungsgeschichte of the fourth Investigation, it also gives a detailed account of its possible implementation in linguistics.

\section{Jakobson}

The fact that Jakobson's version of structural linguistics involves strong influences from Husserl's Logische Untersuchungen is clearly stated at several occasions in Jakobson's oeuvre, but it has only received general recognition after the work of Elmar Holenstein who, in a period of relative phenomenological oblivion during the sixtiesseventies, never ceased to underline the crucial lines of connection between structuralism and phenomenology (Holenstein 1975, 1976). He even traced three or four variants of phenomenology taking each their characteristical departure in the Logische Untersuchungen, as follows (after Holenstein 1976: $58^{6}$ ):

6 The schema is, of course, schematic, and lots of influences cross the main lines
indicated. Thus, it is well known that Heidegger was hugely influenced by the $3^{\text {rd }}$ in- 

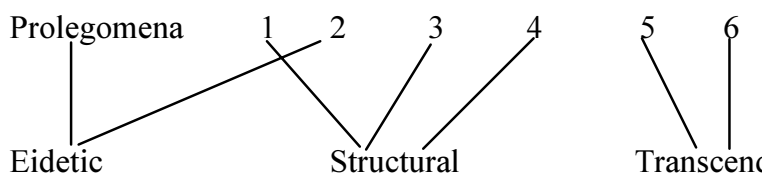

phenomenology phenomenology

München-Göttingen

Prague

phenomenology

structuralism

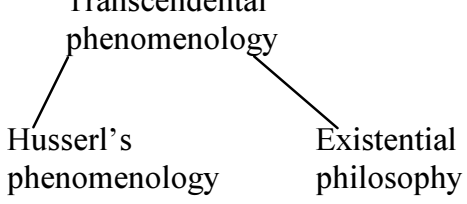

Anti-psychologism (Gestalt psychology)

French phenomenology

$\begin{array}{lll}\begin{array}{l}\text { Autonomous } \\ \text { phenomena }\end{array} & \begin{array}{l}\text { Autonomous } \\ \text { linguistics }\end{array} & \begin{array}{l}\text { Correlation } \\ \text { subject-object }\end{array} \\ \text { Eidetic universals } & \text { Structural universals }\end{array}$

In this respect, the first, third, and fourth Investigations, on the sign, mereology, and pure grammar, respectively, become founding texts for structural semiotics with their emphasis on the possibility of unfolding a set of a priori foundations for the study of semiotic phenomena.

As early as a very young member of the Moscow Linguistic Circle, Jakobson was acquainted with the Logische Untersuchungen through the Russian Husserl disciple Gustav Spet (Jakobson 1985: 281); the Prague Circle which he joined in the twenties was influenced by Husserl through its founder Vilém Mathesius (Jakobson 1971b: 713), and to the end of his life, Jakobson did not cease to emphasize the central role of Husserl in the development of semiotics (Jakobson 1985: 203) and structural linguistics ${ }^{7}$. As a main figure in the Prague Structuralism, Jakobson placed a great emphasis on the 3rd and 4th Logische Untersuchungen especially, and several times he underlined his view of linguistics as a science investigating a hierarchy of wholes

vestigation, just like the $6^{\text {th }}$ investigation's discussion of categorial intuition is important for both eidetic and structural phenomenology.

7 Jakobson (1985: 189). Here, he claims that the 3rd Logical Investigation is "... one of the milestones for the initial advance of structural linguistics ...". 
and parts ${ }^{8}$, and he envisioned language as a whole as a "pattern of relations". In one of his major accomplishments as a linguist, the definition of the phoneme, he used Husserlian concepts not only to underline the anti-psychological character of the phoneme (Jakobson 1971a: 314 ), but also to describe the phoneme as composed of inseparable aspects ('feature bundle'). Jakobson never made one over-all theory of language, convinced as he was that linguistics must be made up of pieces taken from widely differing sources, ranging from anthropology to mathematics, but the mereological issue is also to be found in his most well-known contribution to the formal research of language, his notion of the "marked" versus "unmarked" units of language. His main idea here is that language at many levels makes use of a paradigmatic opposition between parts which are defined by asymmetric dependence?. Markedness is defined as follows: "Eine der wesentlichen Eigenschaften der phonologischen Korrelation besteht darin, dass die beiden Glieder eines Korrelationspaares nicht gleichberechtigt sind: das eine Glied besitzt das betreffende Merkmal, das andere besitzt es nicht; das erste wird als merkmalhaltig bezeichnet, das zweite - als merkmallos ..."10 The opposition between these two is contradictory, in so far the unmarked term does not imply the absence of the feature implied by the marked term, it only implies the absence of any reference to that feature, be it positive or negative. Later, a correlated idea is presented in the theory of zero-signs, referring to the "opposition de quelque chose avec rien", with a Saussure quote (Jakobson 1971b: 213). The marked term is dependent on the unmarked, not vice versa. This asymmetry implies, furthermore, that the unmarked term by Vertauschung may play the role as the more general term of which the marked term forms a part. A semantic example will serve:

8 Like in "Parts and Wholes in Language" where he begins: "In the second part of Edmund Husserl's Logische Untersuchungen - still one of the most inspiring contributions to the phenomenology of language - two studies devoted to "Wholes and Parts" introduce the philosopher's meditations on "the Idea of Pure Grammar". In spite of manifold aspects of interdependence between wholes and parts in language, linguists have been prone to disregard this mutual relationship" (Jakobson 1971b: 280), and further, "The structure of the verbal code is perhaps the most striking and intricate example of whole-part relations that are built hierarchically" (Jakobson 1971b: 282$283)$.

It is a strange fact that Jakobson not explicitly refers to the Logische Untersuchungen in his definitions of the zero-sign or the markedness/unmarkedness distinction. Holenstein $(1975,1976)$ does not mention any such direct influence either.

10 Jakobson (1971b: 3), with reference to Prince N. Troubetzkoy. 

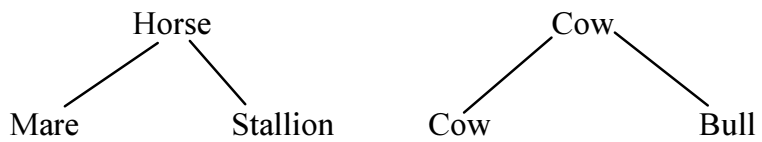

Elephant

The two extremes, horses and elephant, symmetry prevails; there is a mutual dependence between "mare" and "stallion" and a one-sided dependence of both on "horse", so here markedness is used to erect co-ordinate subclasses of a class. In the elephant case, English does not admit special terms for the sexes (except for a duplication of the cow-bull distinction).

With respect to cows, however, "bull" is the marked term, while "cow" is unmarked. This implies two different meanings of "cow", general and specific, respectively. This is to say that in neutral contexts, the unmarked term is used; when you for instance see a field with cows and bulls on it, you can indicate them all by pointing to them and stating: "See the cows", while if one of your children points to a bull and adds: "See the big cow", you will answer: "That's no cow, it is a bull". So the term "bull" is unilaterally dependent on the term "cow". The unmarked term, so Jakobson, has a zero-meaning (in this case, with respect to gender) in contrast to the marked term, but it is characteristical that the semantics of the unmarked term now oscillates between referring to the marked feature being absent on the one hand or referring to the absence of any marked feature on the other. (Cf. the specific and the general use of the word). "Cow" consequently oscillates between entertaining a one-sided and a mutual dependence with "bull". This feature is, of course, not only found at many levels in language structure, but also for pragmatic reasons in use, when you want to single out some (small) marked subset of a set:

"All linguists are stupid, except for cognitive linguists":

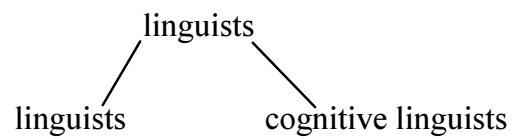

In short, this distinction may be invoked when you want to express that something is part of a larger whole, but yet an atypical part.

Thus, the linguistic distinction between marked and unmarked seems to correspond to a cognitive and phenomenological relation pertaining to prototypicality. If you take as a basis a prototypical case, then the appearance of a non-typical case will possess an ambiguity: it is, on the one hand, part of the category, but, on the other hand, it dif- 


\section{Frederik Stjernfelt}

fers from the prototypical case at the centre of the category. Hence, it is motivated to distinguish this case from the prototypical case, so that a seemingly symmetrical opposition is constructed. Yet, the prototypical case's categorizing power still extends to the marginal case, so that will still be subsumed under its main category. Thus, the marked category is at one and the same time in opposition to the unmarked category and constitutes a subtype of it - the core characteristic of the marked/unmarked relationship. This corresponds to the fact that in semantics, the tendency is that the case considered most normal, widespread, prototypical, stereotypical (or any other typicality measure) case is referred to by the unmarked term, while the less typical case is referred to by the marked term, the marked term's expression typically being longer and more complicated than the unmarked term ${ }^{11}$. Thus, the marked/unmarked distinction finds its foundation in a phenomenological mereology.

\section{Hjelmslev}

A much more ambitious and reflective theory is Louis Hjelmslev's glossematics (partly conceived in cooperation with Hans-Jørgen Uldall). It is probably not very well known that this theory is founded almost unanimously on a mereology. In opposition to Jakobson, however, this theory's relation to the central European mereology is much less clear. Glossematics takes as its point of departure the necessity of basing the cultural sciences taken as a whole on a relation as unanimous as the concept of quantity in natural sciences. This relation is taken to be quality, measured in dependences. The dependence of one phenomenon on another is taken to be the very basis of the theory in Uldall's Outline of Glossematics. In his magistral and beautiful introduction to the glossematic project, Prolegomena to a Theory of Language (Danish Omkring sprogteoriens grundloggelse, 1943), Hjelmslev takes the central object of the theory of language to be the sign, which he analyses as follows:

11 Even politically correct language politics, eager to deconstruct the asymmetry inherent in the markedness-unmarkedness distinction, can not avoid this, cf. long marked forms like "African-American" vs. short unmarked forms like "American". 
expression

content

form

substance

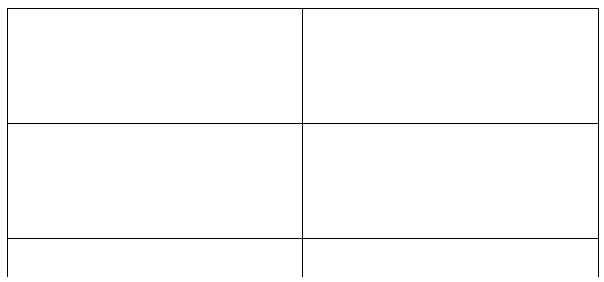

(matter)

The idea, now, is that the central object of the study of language as a system are the two boxes of form. Form of expression and form of content, respectively, are the two areas which may be grasped by glossematics, and even the sign, correlating units from those two domains, does not belong to the linguistic system, but to the use only. This implies that not only the matter of expression and content, respectively, that is, phonetic matter and the phenomenological world referred to is left out of scope, but also expression and content in so far as they are substances formed by linguistic form. As the central object left, the respective systems of form of expression and form of content are now made the objects of linguistic analysis. This is pursued by beginning with the discourse as an undivided whole, and analysis now is supposed to partition this object into invariant parts, named functives, registering the internal function relationship between them. Having exhausted this description at a given level, analysis goes on to repeat the procedure as to the internal structure of the elements, and the procedure is supposed to go on until a bottom of figurae (simple expression and content units) is reached on each of the two domains. Thus, Hjelmslev adheres to what Langacker calls the building block metaphor. The first partitioning is supposed to give the two functives expression and content, thereafter follows (e.g.) periods, sentences, morphemes, etc.

Here, the idea of a glossematic algebra of dependences finds its place. Between two functives on a given level, three so-called functions may be discerned, defined by types of dependence. Three possible dependences may hold between two functives: dependence, interdependence, and correlation (which is the absence of dependence). Dependence occurs when one part requires another for its presence (but not vice versa), interdependence occurs when two parts mutually require each other and consequently only appears together, while con- 
stellation occurs when the occurrence of two parts is free, and both, one, or none of them is equally possible. Hjelmslev now distinguishes between dependences in the domains of linguistic linearisation and system, defined by both-and relations and either-or relations, respectively, which in his vast terminological system are christened selection, solidarity, combination, and specification, complementarity, autonomy, respectively (Hjelmslev 1943: 37). We can illustrate Hjelmslev's idea with an example from the syntactic field. Selection, one-sided dependence, is at stake, for instance, in the relation between main clause and relative clause (a relative clause may not occur without a main clause, while the opposite is not the case). Solidarity, twosided dependence, occurs for instance at the sentence level between noun phrase and verb phrase, and combination, zero dependence, is found e.g. between the two functives of a compound noun.

It is striking that Hjelmslev here as the basis for his theory of language takes three mereological types of dependences very well known in the Brentanist tradition. We find them in Brentano, for instance, and at a prominent place in the 3rd Logische Untersuchungen we find the identical distinction between "gegenseitige", "einseitige", and no relation, respectively (Husserl 1984: 264-265, cf. above).

There is not, however, any mention in Hjelmslev as to where he is inspired to his triad of dependencies which he merely "predicts" for purely formal reasons. While his co-founder of the Copenhagen circle and enemy Viggo Brøndal refers to Husserl, just like their common disciple Diderichsen does decades later, there is no mention of any phenomenological inspiration in the Prolegomena. ${ }^{12}$ At several occasions, Diderichsen remarks upon the complete similarity between the dependence calculi of the Prolegomena and Logical Investigations, but no further explanation is given. ${ }^{13}$ The reasons for this is hard to guess, but three possibilities (at least) are at hand. One is, of course, that Hjelmslev simply came upon the idea of a mereological grammar

\footnotetext{
12 The only reference to Husserl found in Hjelmslev is in the early Principes, but even if it refers to the 4th investigation, it is pejorative: "... la théorie étrange du philosophe HUSSERL" (Hjelmslev 1928: 40).

None of two recent comprehensive treatises on Hjelmslev mentions any possible relation to Husserl (Gregersen 1992, Rasmussen 1992).

13 Diderichsen returns over and over again to the fact that linguistics in general tends to focus upon "three main types of grammatical connexion", and at several occasions he mentions in that context Husserl's mereological analyses from Logische Untersuchungen as strikingly similar to structural linguistics (Diderichsen 1966: 107 [1947], 137 [1948], 207 [1952]) but he yields no indication as to the possible relationship between Husserl and Hjelmslev.
} 
independently; another is that the absence of references is due to the very radical and autonomy-claiming linguistics he is about to found. Unlike his companion Brøndal, much more Jakobsonian in spirit in his reference to the philosophical tradition and to a multiplicity of sources for his version of structuralism, Hjelmslev wants to free himself from any metaphysics, inspired by logical positivism as he is. Maybe he saw too much metaphysical heritage in references to the phenomenological tradition? A third possibility is influence via an intermediate (so as for instance Anton Marty ${ }^{14}$; both Jakobson and Brøndal seem unlikely in that role) or from a common source of inspiration (Brentano).

If we go into the history of glossematics in more detail, an even more complicated relation to mereological considerations shows up. In addition to the dependence calculus of the Prolegomena, Hjelmslev has a further concern with mereological issues in his calculus of socalled "concept zones" (in the content side, approximately corresponding to "semantic domains") and their parts. This idea appears as early as 1933, in the context of the semantic motivation of grammatic categories and in direct discussion with Jakobson's markedness concept (Hjelmslev 1985: 35ff). Jakobson's binarism of course implies that paradigms with three terms must be analyzed as degenerate versions of four-term systems obtained by the combination of two two-term systems. Arguing against binarism, Hjelmslev proposes — probably with inspiration from Brøndal - a tripartition instead of a bipartition of the zone of a given conceptual substance, yielding two opposed parts with a neutral domain between them. (To see which use Hjelmslev makes of these ideas, let us mention his analysis of grammatical numerus which is seen as founded on the concept zone of discrete versus compact, including a neutral zone between them. Hjelmslev 1972: 94f). Interestingly, Hjelmslev calls this calculus "sublogical"; it is inspired by Lévy-Bruhl's idea of "participation" in "primitive" thought where opposed terms may share content. Thus formal logic is supposed to be one possible derivate from this sublogical basis, an idea not unrelated to Husserl's idea of a phenomenological foundation of logic (Husserl 1985).

Such a three-part zone now may be occupied by different terms, defined by placing each their emphasis on differing combinations of

14 Marty, whose 1908 Untersuchungen zur Grundlegung der allgemeinen Grammatik und Sprachphilosophie refers to the Logische Untersuchungen. Hjelmslev refers to Marty at several occasions, but not directly in connection to the dependence algebra. 
the three parts of the zone, this emphasis indicated by a slash in the relevant part(s) of the concept zone:

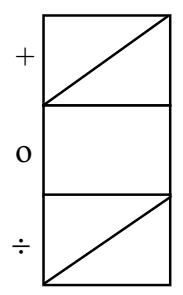

So a term of a paradigm is now seen as a specific combination of the three parts of the paradigm's concept zone. Thus, Jakobson's markedness-unmarkedness distinction corresponds to only two of these possibilities, namely the term occupying only one of the opposed terms (markedness), together with the term indistinctly occupying the whole concept zone (unmarkedness). Thus, unmarkedness is no longer the mere absence of the marked term, unmarkedness is reconstructed as the vague presence of the whole of the concept zone. But the distribution of the emphasis/non-emphasis over the three-part concept zone yields seven possibilities (with the exclusion of the zero case without any emphasis at all) instead of two. Later in the development of glossematics, this calculus is further complicated by the introduction of two emphasis degrees (already in 1934, cf. Hjelmslev 1972), and in the elaborated technical presentation of glossematics in the "Resumé" of the early forties (Hjelmslev 1975), a new set of seven possible emphasis patterns over three-part concept zones is established. These different emphasis terms now combine pairwise to give no less than twelve possible different polar opposites within one and the same concept zone (Hjelmslev 1975: 42), just like systems with from two up to six internally opposed terms appear as a possibility of different emphases of a concept zone (ibid. 31-32). It must be said, though, that the implicit constraints preventing free combination to give an even larger set of possibilities are never made explicit, and neither of the two recent and very thorough reconstructions of Hjelmslev (Gregersen 1992, Rasmussen 1992) are able to make clear the nature and role of these constraints. In our context, it must be added, though, that the concept zone calculus in its "bound" variant is argued to give exactly the three dependence types as a corollary (Hjelmslev 1975: 60). Thus, it might be said that just like in Husserl, an explicitly mereological 
calculus (the partitioning of the concept zone it into three parts and their possible combinations) results in a dependence calculus - even if the route of derivation is much more labyrinthine in Hjelmslev's case and necessitates further research surpassing the scope of this paper. As to the influence question, there seems to be a thin thread leading from the 3rd investigation via Jakobson's markedness concept to Hjelmslev's complicated three-value markedness calculi and further on to his three dependence types — but without any explanation as to how exactly the same dependence calculus appears at each end of that thread.

Anyway, the radical purism in Hjelmslev's dependence calculus as well as in his concept zone calculus also has other conseuences which is my main reason to bring him into the discussion in this context of actual mereological thought. Hjelmslev's purism namely displays some dangers in a too consequent mereological approach. To see this, take Hjelmslev's mereological treatment of linguistic tradition. The whole inventory of morphology and syntax, of distinctions between syllables, words, flections, sentences, hypotaxis, parataxis, etc. must be given up completely in favour of a purely mereological description. We are not supposed to distinguish preposition and government, e.g., in any other way than by knowing that one selects the other, the whole complex of the two again being independent of the clause as a whole on sentence level. The same goes for semantics where the shortcomings of the theory were most easily felt; the consequent mereological approach prohibited any phenomenological semantics in so far as the elements of meaning were allowed to receive purely arbitrary denominations only ${ }^{15}$. Being functives, they were to be referred to by algebraical letters, and their semantic content was supposed to be read off their mereological dependencies only ${ }^{16}$. In lexical semantics, the theory restricted itself to banalities such as that the meaning of "bull" was dependent on the meanings of "ox" and "male", respectively.

\footnotetext{
15 Here, Diderichsen is admirably clear in his early insistence that formal glossematic description is impossible without a prior phenomenological sensibility for identities and differences (Diderichsen 1966: 123 [1948]).

16 This consequence is still visible in Greimasian semiotics, having inherited the whole of its metatheoretical apparatus from the Prolegomena. In the semiotics of the Paris school, the orthodoxy teaches that denominations of theoretical as well as metatheoretical terms are completely arbitrary; still they are invariably chosen so they are relatively easily understandable with reference to ordinary language or linguistic tradition.
} 
What is to be learned from the partial failure of Hjelmslev's grand mereological project? The set of restrictions which the theory admits deliberately cuts it off from possible insights, first in the letting out of sight language's reference to any context ("matter"), and second in its dogmatic decision that any relation between expression is content is merely arbitrary. Both these ideas have been excellently attacked by the cognitive semantics tradition ${ }^{17}$. The main implication in this context, however, to be drawn concerns the consequences of the idea of a purely mereological dependence calculus used as a descriptive metalanguage. Such a calculus so to speak conceives its object from outside, sees it constructed by discrete building-blocks holding a highly restricted set of dependencies between them. To describe language and other semiotic phenomena (which is, implicitly, the ambition of glossematics, the matter of expression being of secondary importance) it is necessary not to delimit oneself beforehand to one selected calculus (even if it is a fertile one) of description. Moreover, Hjelmslev's use of it repeats some of the Berlin School's less lucky consequences without gaining its advantages: Hjelmslev ceases to use traditional linguistic terminology, so that for instance morphology versus syntax should be mereologically reinterpreted. But doing so, the Graz School advantage of being able to distinguish a part (a word's morphology) from the role played (in sentence syntax) in a gestalt, is lost.

Another drawback is extremely discontinuous character of the calculus, given by the definition of the dependence calculus to hold between well-defined units of a lower level (which is not a necessary implication by dependence calculi). All continuous phenomena in signification is a priori bracketed by the choice of so restricted a metalanguage (on the linguistic expression side intonation, prosodic features, gestures; on the content side the whole question of continuous schemata and their (continuous) eidetic variation in semantic description.)

Finally, a drawback is a fact which Barry Smith has often referred to: mereology's explicit and admitted weakness. In Lesniewski's version, this was even picked as a special privilege of the theory, making it independent of ontological assumptions. The flip side of this is that mereology's weakness makes it unfit to describe most empirical wholes without further formal equipment. In linguistics, this further equipment is most often tacitly presupposed - in for instance the idea

17 For instance Ronald Langacker at the "Wholes and their Parts" conference in Bolzano 1998, where this paper was presentedgiven. 
of co-existence of terms in a sentence. But dependence relations does not in any way imply the existence of parts in the same place. A whole consisting of the tone A, my left shoe and the contour of England is perfectly admissible. Contiguous wholes thus require at least additional topologies for their description, making it possible to distinguish connected and non-connected wholes - and they may require metrics, spatio-temporal embedding and much more in order to map further properties of interest; this goes for objects in general as well as for objects of semiotics specifically. Mereology and its dependence calculi do remain a very important formal part of semiotics, but we have no reason to assume that they exhaust the formalisms necessary, just like a considerable work in formal ontology will be required to yield a more refined taxonomy of gestalt types.

\section{Peirce}

Consequently, a much more liberal stance must be taken with respect to which forms may count as significant. A reflection of this kind, also with mereological implications, is found in Charles Peirce, albeit in two of the less well-known corners of his theory, namely in his theories of diagrams and of abstraction, respectively ${ }^{18}$. As is probably

\footnotetext{
18 Peirce's explicit interest in the whole-part issue is delimited to the article on that subject in Baldwin's dictionary. Here, he finds that a whole is always a collection which is no easily defined concept; moreover, it is, just like in large parts of the Brentano tradition, an ens rationis, an abstraction on the basis of more concrete parts. Just like the more sensitive parts of this tradition, Peirce will admit both subjective and objective wholes. He concludes this small article with a alphabetical botanics of whole types which he does not pursue further, but which may be interesting to quote here (Peirce 1998, 1: 383):
}

"Many adjectives are used to distinguish different kinds of wholes. Certain of the phrases may be defined.

Actual whole: any whole which cannot exist without the existence of its parts. Usually identified with the Constitute whole. Monboddo's definition (Ancient Met., i. 479) is not quite accurate.

Collective whole, or aggregate whole: defined by Chauvin as "that which has material parts separate and accidentally thrown together into one, as an army", etc. But the example shows that organization does not disqualify a whole from being called collective, although the term totum per aggregationem will no longer be applied to it, in that case. In so far as a whole is collective, any other relation between its parts is put out of view.

Composite whole: a term of Burgersdicius, who (Inst. Met., I. xxii. §7) defines it as quod ex duabus partibus constat quarum una est in potentia ad alterum et altera 
vice versa actus est alterius. It includes the whole by information and the whole by inherence.

Comprehensive whole: a whole of logical comprehension.

Constituent whole: a whole which is essential to its parts.

Constitute whole: a whole whose parts are essential to it. See Actual whole (above).

Continuous whole: a continuum regarded as a whole. In order to define it, it would first be necessary to define continuity. Now we have, perhaps, not yet succeeded in analyzing the conception of continuity; for what the mathematicians call by that name, such as the relations of all real quantities capable of being designated to an indefinite degree of approximation by means of a whole number and a decimal, does not answer the requisites of the problem.

Copulative whole: a whole consisting of a sign which is essentially applicable to whatever certain signs, called its parts, are all applicable, but is essentially inapplicable to anything to which any one of these signs is inapplicable.

Definite whole: a whole constituted by genus and difference.

Definitive whole: see Definite whole (above).

Discrete whole: the same as a Collective whole (above).

Disjunctive whole: a whole consisting of a sign which is essentially applicable to whatever any one of certain signs, called its parts, is applicable, but is essentially inapplicable to anything to which none of these parts is applicable.

Dissimilar whole: same as Heterogeneous whole (below).

Essential whole: great confusion exists in the use of this very common expression. Aquinas (Summa Theol., Pt. I. lxxvi. 8) uses it in a broad sense which would make it about equivalent to Burgersdicius' composite whole, or perhaps broader. On the other hand, it is sometimes restricted to the whole per informationem, and this is perhaps the best settled use. But others make it include the physical and the metaphysical whole as its two species.

Extensive whole: a whole of logical extension, usually called a subjective or logical whole.

Formal whole: a comprehensive whole, especially of essential comprehension. See Actual whole (above).

Heterogeneous whole: a term of Aquinas; a whole whose parts are dissimilar from the whole.

Homogeneous whole: a term of Aquinas; a whole whose parts are similar to the whole, as the parts of a whole of water are.

Integral whole (a term in common use since Abélard's time): Blundevile (1599) says, "Whole integral is that which consisteth of integral parts, which though they cleave together, yet they are distinct and severall in number, as man's body, consisting of head, brest, belly, legs, etc." The usual definition is quod habet partem extra partem, which restricts it to space. Burgersdicius, however, says that parts which differ in their ordinal places are partes extra partes.

Integrate whole: a pedantic variant of Integral whole (above).

Logical whole: same as Universal whole (below).

Mathematical whole: same as Integral whole (above).

Metaphysical whole: a whole in that respect in which a species is the whole of its genus and difference. See Formal whole (above). 
well known, one of the main projects of Peirce's philosophy is the classification of signs - signs in general, including the signs used in the sciences, so that his theory by the same token becomes an epistemology. A crucial part of this epistemology connects the two issues of diagrams and abstraction (which, if taken separately, form rather remote and seemingly insignificant branches in Peirce's vast tree of triparting distinctions ${ }^{19}$ ).

Natural whole: a term proposed by Hamilton to replace Comprehensive or Metaphysical whole; as if that were not sufficiently provided with aliases under which to hide itself.

Negative whole: a unit regarded as a whole, as in the phrases deus totus est ubique, and anima est tota in toto corpore.

Physical whole: a whole compounded of substance and accident; but some say of matter and form; and some that both come to the same thing. In the peripatetic view, however, substance is form, not matter.

Positive whole: a whole consisting of parts. See Negative whole (above).

Potential whole: same as Universal whole (below); so called because the genus does not actually, but only potentially, contain the species, etc.

Potestative whole: a term of Aquinas; equivalent to Potential whole (above).

Predicative whole: a whole of logical depth.

Quantitative whole: same as Integral whole (above).

Similar whole: see Homogeneous whole (above).

Subject whole: same as Subjective whole (below).

Subjective whole: a very venerable name for Universal whole (below).

Substantial whole: a whole of logical breadth.

Universal whole: see Universal.

Whole by accident: such a whole as neither essentially belongs to the parts nor the parts to it.

Whole by aggregation or aggregative whole: same as Collective whole (above) in an exclusive sense.

Whole by information: a compound of act and power in the same kind, such as man, according to the Aristotelian theory of the soul.

Whole by inherence: same as Physical whole (above).

Whole by itself or per se: a whole which essentially belongs to its parts or its parts to it."

19 Thus, as to diagrams, they are a subspecies of icons. One of Peirce's most famous classifications is the tripartition of signs as to their reference to their object which may take place due to similarity, cause, or convention, giving icons, indices, and symbols, respectively. Now these three are not species of a genera, they are rather to be conceived of as Russian dolls, so that indices typically involve icons, and symbols involve both the simpler types of signs. Now, the category of icons is in turn subdivided again, into images, diagrams, and metaphors. The first icons are like their object with respect to a simple quality, the second due to interrelations between its parts, and the third locates a similarity in a third object.

As to hypostatic abstractions, they form a triad together with concrete signs and collective signs (referring to individuals and collections, respectively), all of them 
The crucial thing in this respect is that to Peirce, abstract diagrams are the machines for all necessary reasoning. It is important here to notice, that the definition of icons as signs by similarity is not trivial; it is expanded into the definition that an icon is a sign by the contemplation of which it is possible to discover new truths not stated in the construction of the icon. When this is applied to the subtype of icon called diagram, this implies that by the contemplation of the interrelation of parts in a whole you may discover new properties not stated in the construction recipe for it. When we want to reason about anything, be it empirical or apriorical, we imagine a diagram of it, and then we observe the diagram while we perform manipulations of it. Diagrams thus forms a very general concept in Peirce, including for instance geographical maps, machine instructions, geometrical figures, graphs, mental maps, schemata etc. This broad generality is one of the great points in the concept, being at the same time a basically mereological concept $^{20}$.

The diagram is a stylized picture of its object - and this stylization involves two kinds of abstractions. One is the so-called "prescission", the second of Peirce's three distinction types, dissociation, prescission, and discrimination, respectively. These separation types, in fact, form the equivalent in Peirce to the dependence calculi we isolated in the other three semioticians. Dissociation separates independent objects; prescission separates objects which may be supposed to exist separately; discrimination separates objects which may only be represented separately. The precise relation between these distinction types and the dependence calculi of Husserl and Hjelmslev has not been established yet, but the following is a first attempt: dissociation is the distinguishing ability corresponding to constellation in Hjelmslev and independence in Husserl, while prescission separates a founding part from a founded part and discrimination vice versa (so that interdependent parts may only be discriminated, while unilaterally dependent parts may be prescinded (the independent part) or discriminated (the dependent part).

When making a diagram, we must prescind it from the particular token drawn on a piece of paper so as to grasp it as an ideal object. Furthermore, the activity we may picture with a diagram by manipu-

subtypes of singular objects which, in turn, form a triad of signs for immediate objects, including vague signs, singular signs and general signs.

20 On the crucial role played by diagrams in the mature Peirce's thought, see Stjernfelt (2000). 
lating it, may itself be made the object of a higher-order diagram. This is "hypostatic abstraction" in Peirce's system, to be sharply distinguished from the distinction types: it makes a noun out of a predicate and thus makes it possible further to investigate the properties of this predicate. Prescission thus is a focussing mechanism, leading to the predicative isolation of still more general properties of an object while abstraction is an objectifying mechanism, making an object of thought out of a predicate, or, as Peirce puts it sloganlike, it makes a thing out of a thought.

Now, in addition to arise by means of prescission, the diagram be it empirical or pure - forms a whole consisting of interrelated parts. The character of the interrelations make certain experiments possible, and these experiments are now interpreted as holding also for the object depicted:

Deduction is that mode of reasoning which examines the state of things asserted in the premisses, forms a diagram of that state of things, perceives in the parts of that diagram relations not explicitly mentioned in the premises, satisfies itself by mental experiments upon the diagram that these relations would always subsist, or at least would do so in a certain proportion of cases, and concludes their necessary, or probable, truth. For example, let the premiss be that there are four marked points upon a line which has neither extremity nor furcation. Then, by means of a diagram,

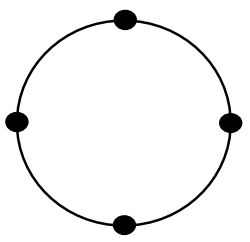

we may conclude that there are two pairs of points such that in passing along the line in any way from one to the other point of either pair, one point of the second pair will be passed an odd number of times and the other point an even (or zero) number of times. This is deduction. (Peirce $1998,1: 66)^{21}$

\footnotetext{
21 The shortest presentation is probably: "For mathematical reasoning consists in constructing a diagram according to a general precept, in observing certain relations between parts of that diagram not explicitly required by the precept, showing that these relations will hold for all such diagrams, and in formulating this conclusion in general terms. All valid necessary reasoning is in fact thus diagrammatic" (Peirce 1.54). The object of mathematics will be pure diagrams of any kind, while ordinary reasoning as
} 
Take for instance a geographical map - a continuous diagram constructed by triangulation from selected points in the landscape. I can now perform the experiment on the diagram, measuring with a yardstick and dividing with the scale — showing that there is 40 miles from Bolzano to Trento - even if this information did not have any place at all in the construction of the map. To Peirce, this definition of diagram includes even algebra - in so far as it is possible to manipulate algebraic formulae in order to obtain new information (solving equations, e.g.), algebra must be counted among the central subtypes of diagrams.

It is an important feature of diagrams that they are at the same time general and observable (in this way they are Peirce's version of the Schemata of Kant's 1st Critique, uniting concepts and intuition). They permits us to see, in a token drawing, a diagram type, and hence that the manipulation we undertake is generally valid for a whole class of related manipulations, not only the single one undertaken on the diagram drawing. An important diagrammatical operation is the working together of prescission with abstraction, that is, a diagram property is selected as an object which may itself be subject to rule-governed manipulation. Abstraction permits the diagram to be recursive and embed one diagram with its whole set of procedures as an object in a more abstract diagram making it possible to investigate the first one. To stay in the map example, we can for instance generalize from the single map and abstract the subject of "mapness", leading to the question of possible projections giving rise to maps with various properties. In Husserlian slang, this makes possible to investigate still more abstract moments as if they were Stücke.

The strength of the diagram category is that it - in contrast to the dependence calculi of the early Husserl and of glossematics - displays the wide variety of (not only) mereological devices used in the construction of meaning. In any case, namely, a diagram analyses its object into a collection of interrelated parts, the relations of which may be specified in many terms in addition to dependence: connectedness, boundedness, quantity, locality, form, metric relations ... But in all cases the relations between the parts must be " rational", that is, they must be defined clearly in order to facilitate unambiguous dia-

well as the empirical sciences will use the same diagrams while being constrained by the appearance of the world as well. 
gram manipulation. Thus, they include all relations giving possibly rise to necessary reasoning ${ }^{22}$.

\section{To conclude}

The four semioticians discussed here all include mereological investigations at central points of their thought - but they do not ascribe it the same role. In Husserl, it forms a crucial part of formal ontology, relevant for any ontological domain whatsoever (but not necessarily with any claim for being exhaustive for formal ontology), and it subsequently plays a central role in his pure grammar. In Hjelmslev, exactly the same calculus is supposed to be the formalism relevant to describe all possible formal properties in semiotic systems as a presuppositionless metalanguage deprived of any of the ontological ambitions of phenomenology. Yet, Husserl's refusal that "vague morphologies" may be formalized, may approach him to Hjelmslev, and their strong reliance on dependence calculi may probably have its reason in their reliance on the former's weak, methodological reliance upon logic, and the latter's strong methodological reliance upon language, respectively, both being discontinuous systems. Jakobson, on the other hand, makes a less theoretical use of mereology, but his theory points towards a pragmatical grounding of mereology in prelinguistic, phenomenological perception of wholes with atypical parts generalizing the experience of discovery: the sudden appearance of a new, strange phenomenon within the bounds of the supposedly wellknown. Peirce, finally, from a classificatory point of view, yields the least explicit, but most comprehensive mereology, including continuous mappings of all sorts, delimited by the efficacity constraint of the pragmatic maxim only.

Thus, all four of them may contribute to the ongoing investigation of mereology's role in semiotics. Hjelmslev's and Husserl's precise

\footnotetext{
22 Maybe this very general notion of diagram - parts with unspecified interrelations being open to abstraction to classes of interrelations - makes Peirce's schema an early forerunner of category theory. Finally, I imagine Peirce's very wide concept of diagram can not only generalize Kant's idea of a schema, but also serve as a unifying concept for the various schema-like ideas that prevail in present-day cognitive semantics (image schemas, force dynamics, landmark-trajectory, etc.). If so, then the semantic processes mapped in this tradition - metaphorical mapping, blending, conceptual extension etc. - would be understandable as specific variants of manipulation on a diagram.
} 
dependence calculi from one side - freed from the former's exhaustibility claims and fear for ontology — Jakobson's empirical and pragmatic fertilization of these ideas - and as a general framework, Peirce's sketch of a diagrammatic semiotics including dependence calculi in its prescission theory and whole-part mappings in its diagram theory. The integration of these insights should make the relation between semiotics and mereology a serious challenge.

\section{References}

Cassirer, Ernst 1945. Structuralism in modern linguistics. Word: Journal of the Linguistic Circle of New York 1(2): 99-120.

Diderichsen, Paul 1966. Helhed og struktur: Udvalgte sprogvidenskabelige afhandlinger. København: G. E. C. Gad. [In German: 1976. Ganzheit und Struktur: Ausgewählte sprachwissenschaftliche Abhandlungen. München: Fink.]

Gardies, Jean-Louis 1985 Rational Grammar. München: Analytica [orig. 1975].

Gregersen, Frans 1992. Sociolingvistikkens (u)mulighed [The (Im)Possibility of Socio-Linguistics]. Copenhagen: Tiderne Skifter.

Hjelmslev, Louis 1928. Principes de grammaire générale. Copenhagen: Høst og Søn.

- 1943. Omkring sprogteoriens grundlaggelse. Copenhagen: Munksgaard [Eng. version Prolegomena to a Theory of Language, 2nd. ed. Madison: The University of Wisconsin Press 1969].

- 1972. Sprogsystem og sprogforandring. [Language System and Language Change. 1934]. Copenhagen: Nordisk Sprog- Og Kulturforlag.

- 1975. Resume of a Theory of Language. Copenhagen: Nordisk Sprog- og Kulturforlag (approx. 1943).

- 1985. Nouveaux essais. Paris: PUF.

Holenstein, Elmar 1975. Roman Jakobsons phänomenologischer Strukturalismus. Frankfurt/M: Suhrkamp.

- 1976. Linguistik, Semiotik, Hermeneutik. Frankfurt/M: Suhrkamp.

Husserl, Edmund 1970. Philosophie der Aritmetik (Husserliana XII). Den Haag: Martinus Nijhoff.

- 1975. Logische Untersuchungen I (Husserliana XVIII). Den Haag: Martinus Nijhoff.

- 1979. Aufsätze und Rezensionen (1890-1910) (Husserliana XXII). Den Haag: Martinus Nijhoff.

- 1984. Logische Untersuchungen II, I.-II Teil (Text nach Husserliana XIX/1-2). Hamburg: Felix Meiner.

- 1985. Erfahrung und Urteil. Hamburg: Felix Meiner. 
Jakobson, Roman 1971-1985. Selected Writings I (1971), II (1971), VII (1985). Berlin: Mouton.

Luschei, Eugene C. 1962. The Logical Systems of Lesniewski. Amsterdam: North-Holland Publishing Company.

Münch, Dieter 1993. Intention und Zeichen: Untersuchungen zu Franz Brentano und zu Edmund Husserls Frühwerk. Frankfurt/M: Suhrkamp.

Peirce, Charles S. 1976. New Elements of Mathematics I-IV. (C. Eisele, ed.). The Hague: Mouton.

- 1998 [1931-1958]. Collected Papers, I-VIII. London: Thoemmes Press.

Rasmussen, Michael 1992. Hjelmslevs sprogteori. [Hjelmslev's Theory of Language]. Odense: Odense Universitetsforlag.

Smith, Barry (ed.) 1982. Parts and Moments: Studies in Logic and Formal Ontology. München: Philosophia Verlag.

- 1994. Austrian Philosophy. Chicago: Open Court.

- (forthcoming). Logic and formal ontology. In: Manuscrito.

Stjernfelt, Frederik 1992. Categorical perception as a general prerequisite to the formation of signs? On the biological range of a deep semiotic problem in Hjelmslev's as well as Peirce's semiotics. In: Sebeok, Thomas A. and Umiker-Sebeok, Jean (eds.). Biosemiotics: Semiotic Web 1991. Berlin: Mouton de Gruyter, 427-454.

- 1992. Formens betydning: Katastrofeteori og semiotik [The Meaning of Form: Catastrophe Theory and Semiotics]. Copenhagen: Akademisk Forlag.

- 1997. Rationalitetens himmel [The Heaven of Rationality]. Copenhagen: Gyldendal.

- 1999. Biosemiotics and formal ontology. Semiotica 127(1/4): 537-566.

- 1999. How to learn more: An apology for a strong concept of iconicity. In Johansson, T. D.; Skov, Martin and Brogaard, Berit (eds.), Iconicity: A Fundamental Problem in Semiotics. Aarhus: NSU Press, 21-58.

- 2000. Diagrams as centerpiece of a Peircean epistemology. Transactions of the Charles S. Peirce Society 36(3): 357-384.

- (forthcoming a). Categories, Diagrams, Schemata. In: Stjernfelt, Frederik and Zahavi, Dan (eds.), 100 Years of Phenomenology - Logische Untersuchungen Centenary.

- (forthcoming b). Biology and abstract schemata. In: Brogaard, Berit and Smith, Barry (eds.), Rationality and Irrationality.

- (forthcoming c). A Natural Symphony? To what extent is Uexküll's Bedeutungslehre actual for our day's semiotics. Semiotica.

- (forthcoming d). Die Vermittlung von Anschauung und Denken: Semiotik und Schematismus bei Kant, Cassirer und Peirce. Zeitschrift für Semiotik.

Uldall, Hans-Jørgen 1967. Outline of Glossematics. Copenhagen: Nordisk Sprog- og Kulturforlag.

Willard, Dallas 1982. Wholes, parts, and the objectivity of knowledge. In: Smith, Barry (ed.), Parts and Moments: Studies in Logic and Formal Ontology. München: Philosophia Verlag, 379-400. 


\section{Мереология и семиотика}

Статья дает обзор роли мереологии - теории частей и цельх - в семиотике. Коротко представлена мереология четырех крупнейших семиотиков - Гуссерля, Якобсона, Ельмслева и Пирса, описывается роль мереологии в общем строении их теорий со ссылкой на традицию Брентано. Наконец, предпринята оценка сильных и слабых сторон этих ученых и предлагаются некоторые перспективы дальнейших исследований.

\section{Mereoloogia ja semiootika}

Artiklis antakse ülevaade mereoloogia (teooria osadest ja tervikust) rollist semiootikas. Lühidalt esitletakse nelja suure semiootiku - Husserli, Jakobsoni, Hjelmslevi ja Peirce'i - mereoloogiat ja kirjeldatakse mereoloogia osa nende teooriate ülesehituses juhindudes Brentano traditsioonist. Püütakse anda hinnangut nimetatud teadlaste tugevatele ja nõrkadele külgedele ja pakutakse välja mõningad uued uurimissuunad. 